\title{
NOTES ON HIPPOBOSCIDAE
}

\section{A TENTATIVE KEY TO THE SPECIES OF OLFERSIA WIEDEMANN (FERONIA LEACH; PSEUDOLFERSIA COQUILLETT).}

\section{By J. BequaERT}

Department of Tropical Medicine, Harvard Medical School, Boston, Mass.

A prolonged study of extensive material has led me to recognize more species of Olfersia than is customary at present. Pending the more detailed publication of my results, I offer herewith a key to the species which I regard as valid. Full acknowledgments will be given later; but I wish to thank now Prof. G. F. Ferris for entrusting me with his entire collection of the genus, as well as Mr. J. E. Collin for the detailed study of Bigot's types which he made at my request.

\section{Key to Species}

1. First basal cell ( $R$ ) short and wide, distinctly bulging before the apex; fourth longitudinal vein $\left(\mathrm{M}_{1+2}\right)$ partly setulose. First tergal plate of abdomen triangularly excised at apex in male, divided into two median lobes in female. O. sordida Bigot. First basal cell (R) long and narrow, its apical half parallel-sided or nearly so; fourth longitudinal vein $\left(\mathrm{M}_{1+2}\right)$ bare throughout. Apical margin of first tergal plate straight or slightly curved inward 2.

2. Posterior orbits (above eyes) about as long as or barely shorter than the greatest width of the inner orbits; occipital margins of posterior orbits and of postvertex (or vertical plate) strongly produced behind and separated from one another by deep curved notches. Lower, frontal area of postvertex alutaceous, separated from the upper, smoother area by a slight transverse depression 
Posterior orbits much shorter than the greatest width of the inner orbits; occipital margins of posterior orbits and of postvertex scarcely produced and separated by shallow curves

3. Occipital margin of postvertex somewhat more produced behind than the posterior orbits. Third longitudinal vein $\left(R_{4+5}\right)$ setulose throughout. Cross-vein closing second basal cell very oblique, the upper outer angle of the cell acute ................................. O. spinifera (Leach). Occipital margins of postvertex and of posterior orbits about equally produced behind. Third longitudinal vein either bare or at most with a few setæ toward apex. Cross-vein closing second basal cell nearly vertical, the upper outer angle of the cell almost square.

A. erythropsis Bigot.

4. Second basal cell (M) very short; second section of fourth longitudinal vein $\left(\mathrm{M}_{1+2}\right)$ about twice as long as first section of fifth $\left(\mathrm{M}_{3+} \mathrm{Cu}_{1}\right)$. Frons not or hardly wider than an eye. Postvertex not divided by a transverse depression from the lower, frontal area. Third longitudinal vein $\left(R_{4+5}\right)$ with minute setæ, as a rule on apical portion only O. bisulcata Macquart. Second basal cell long; second section of fourth longitudinal vein at most one and one-third times the length of the first section of the fifth (often about the same length)

5. Third longitudinal vein $\left(R_{4+5}\right)$ distinctly setulose throughout. Postvertex not divided by a transverse depression from the lower, frontal area. Frons narrow, not or hardly wider than an eye

$$
\text { O. fumipennis (Sahlberg). }
$$

Third longitudinal vein bare or at most with a few minute setæ on apical portion

6.

6. Postvertex not divided by a transverse depression from the lower, frontal area, extending as one smooth and shiny plate from the occiput to the fronto-clypeus. Frons at least one and one-third times as wide as an eye. Wing 7 to $9 \mathrm{~mm}$. long O. fossulata Macquart. 
Postvertex divided by a slight transverse depression into an upper, smooth and shiny area and a lower (frontal) portion which is more or less dull. Frons about one and one-fifth times as wide as an eye, rarely slightly more. Wing 6 to $8 \mathrm{~mm}$. long. O. coriacea v.d. Wulp.

The synonymy, characters, distribution and hosts of the several species will be fully discussed later. The following remarks are preliminary:

\section{Olfersia sordida Bigot}

According to Mr. J. E. Collin, Bigot's type is a male and shows the characters here given for the species. Originally described from Guatemala, O. sordida is widely distributed in North America. I have seen it from Oregon, Louisiana, Florida, the Bahamas, St. Thomas (W. I.), Jamaica, Trinidad, Mexico and Panama. The usual host is the Brown Pelican, Pelecanus occidentalis Linnaeus; but I have also seen it from the Florida Cormorant, Phalacrocorax auritus floridanus (Audubon).

\section{Olfersia spinifera (Leach)}

I regard Ornithomyia unicolor Walker, Olfersia courtilleri "Fairmaire" Courtiller, and Olfersia sulcifrons C. G. Thomson as synonyms of $O$. spinifera. I have seen specimens of true spinifera from Florida, Louisiana, the Bahamas, the Galapagos, the coast of Brazil, Nihoa Island (near Hawaii), and the Solomon Islands. Most specimens came from Frigate or Man-o-War birds (species of Fregata) ; but I have seen a few taken off Pelicans and Cormorants.

\section{Olfersia erythropsis Bigot}

This species has been generally confused with $O$. spinifera. It is identical with Pseudolfersia diomedex Coquillett, the types of which I have seen at the U. S. National Museum. The type of O. erythropsis, studied by Mr. J. E. Collin, has all the characters of diomedeæ. I have seen the species from the Bahamas, Desecheo Island (near Porto Rico), the Galapagos, Moorea (one of the Tahiti Group), 
and Ponape (one of the Caroline Islands). The hosts known to me are the Albatross, Diomedea irrorata Salvin; the Redtailed Tropic-bird, Phaëthon rubricauda Boddaert; the White-bellied Booby, Sula leucogaster (Boddaert), and the Small Noddy, Anous minutus Boie.

\section{Olfersia bisulcata Macquart}

The type of this species passed into the Bigot Collection and is now the property of Mr. J. E. Collin. According to his detailed account, it has all the characters of the wellknown Olfersia vulturis van der Wulp, a name which will pass in the synonymy. O. bisulcata, originally described from Chile, is a common species throughout Central and South America. I have seen it from Mexico, Yucatan, Guatemala, Panama, Venezuela, Brazil, Bolivia, Peru, and British Guiana. O. vulturis was described from Costa Rica. The usual hosts are the South American Vultures, Catharista urubu (Vieillot) [=Coragyps atratus (Meyer)], Gypagus (or Sarcoramphus) papa (Linnaeus), and Cathartes aura (Linnaeus) ; but there are also records from Turkey Buzzard, smaller Hawks and Condor.

\section{Olfersia fumipennis (Sahlberg)}

Pseudolfersia maculata Coquillett, of which I saw the holotype at the U. S. National Museum, is in my opinion identical with $O$. fumipennis, originally described from Finland. The species appears to be very rare in Europe, since I have been unable to find another record from that part of the world. In North America, however, it is one of the common hippoboscids. I have seen specimens from Vermont, Massachusetts, New Hampshire, Wisconsin, Michigan, Minnesota, New York, New Jersey, Pennsylvania, Virginia, North Carolina, Florida, Louisiana, Texas, Kansas, and Cuba. In most cases the host is the Osprey or Fishhawk, Pandion haliaetus (Linnaeus) [typical form in Finland; race carolinensis (Gmelin) in North America]; but a few specimens have been taken off Loon, Gavia immer (Brünnich), Bald Eagle, Haliaeetus leucocephalus (Linnaeus), and Hawks. 


\section{Olfersia fossulata Macquart}

Originally described from Brazil, this species is widely distributed in South America. I have seen it from Desecheo Island (near Porto Rico), Peru (near Lima, as well as on the Guano Islands), and Chile. Seven specimens from the Philippine Islands undoubtedly belong to this species. The chief hosts are certain tropical marine birds, such as the Peruvian Cormorant or Guanay, Phalacrocorax bougainvillei (Lesson) ; Belcher's Gull, Larus belcheri Vigors; the White Gannet, Sula variegata (Tschudi) ; and the Pelican, Pelecanus thagus Molina. These four birds nest in enormous numbers on the Guano Islands off the coast of Peru, where $O$. fossulata often swarms in the rookeries, even over bare rocks.

\section{Olfersia coriacea van der Wulp}

Pseudolfersia meleagridis Lutz, Neiva and da Costa Lima I regard as a synonym. Thus far I have seen $O$. coriacea from southern Mexico, Guatemala, Panama, British Guiana, Bolivia and Brazil. Its hosts are various wild gallinaceous birds, notably the Crested Curassow, Crax globicera (Linnaeus). The species has been discussed in an earlier paper [1932, Psyche, XXXVIII, (1931), p. 186]. It was then suggested that Olfersia mexicana Macquart might be the same; but, according to information recently received from $\mathrm{Mr}$. E. Séguy, Macquart's type in the Paris Museum is apparently a specimen of Ornithoctona erythrocephala (Leach). On the other hand, Mr. J. E. Collin writes me that the specimen called "Olfersia mexicana" in Bigot's collection is a true Olfersia and not separable from O. bisulcata Macquart.

The following names and descriptions evidently were based upon species of Olfersia. Most probably they are synonyms of one or another of the forms studied above.

Olfersia aenescens C. G. Thomson, from Keeling Island, off an unknown host. The type is at the Stockholm Museum. According to Speiser, who saw the specimen, the postvertex is not divided by a transverse depression. I suggest that it was $O$. fossulata Macquart.

Olfersia mycetifera (Speiser), from Senafir, on the African shore of the Red Sea, off an Eagle. Most probably this was O. fumipennis (Sahlberg). 

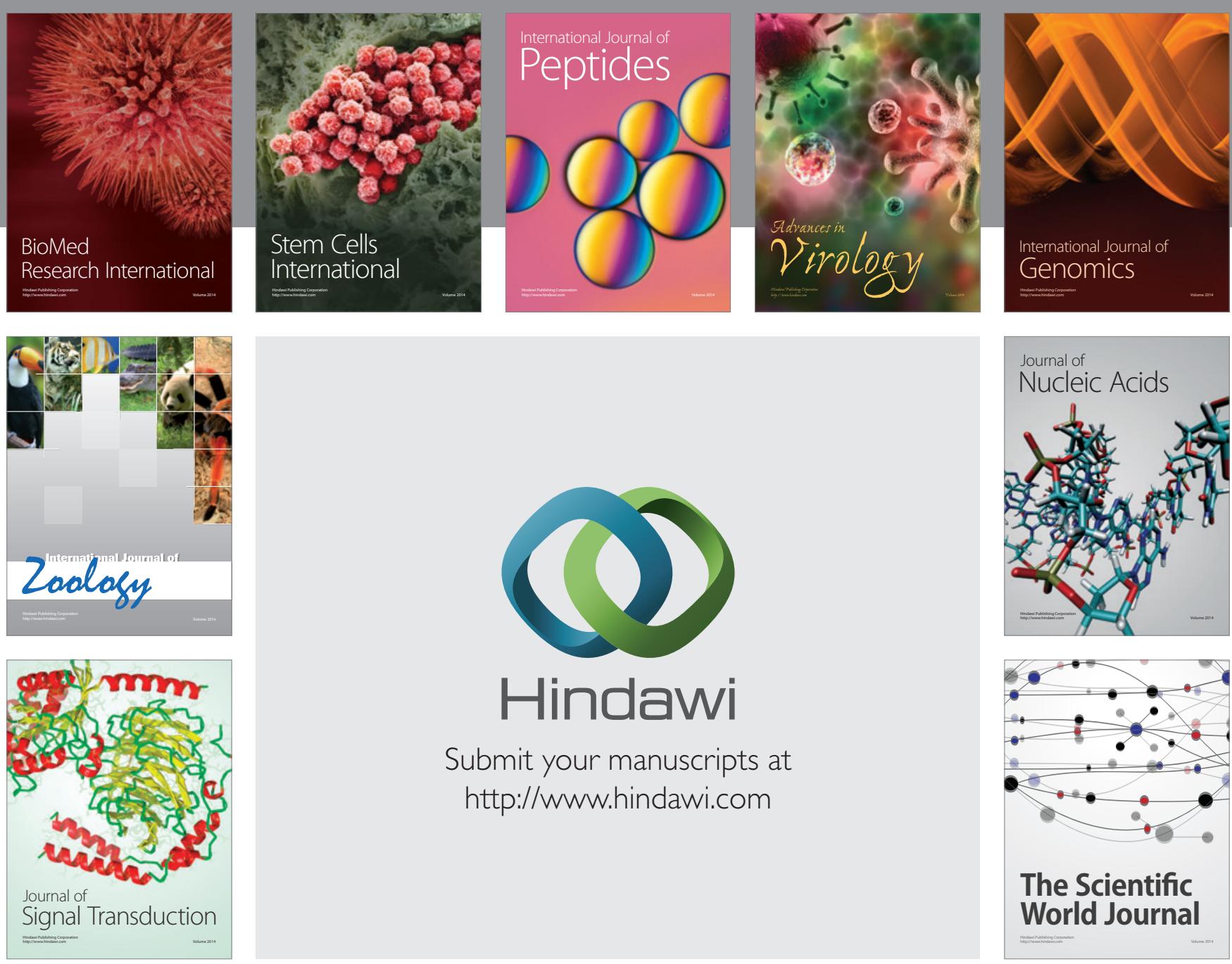

Submit your manuscripts at

http://www.hindawi.com
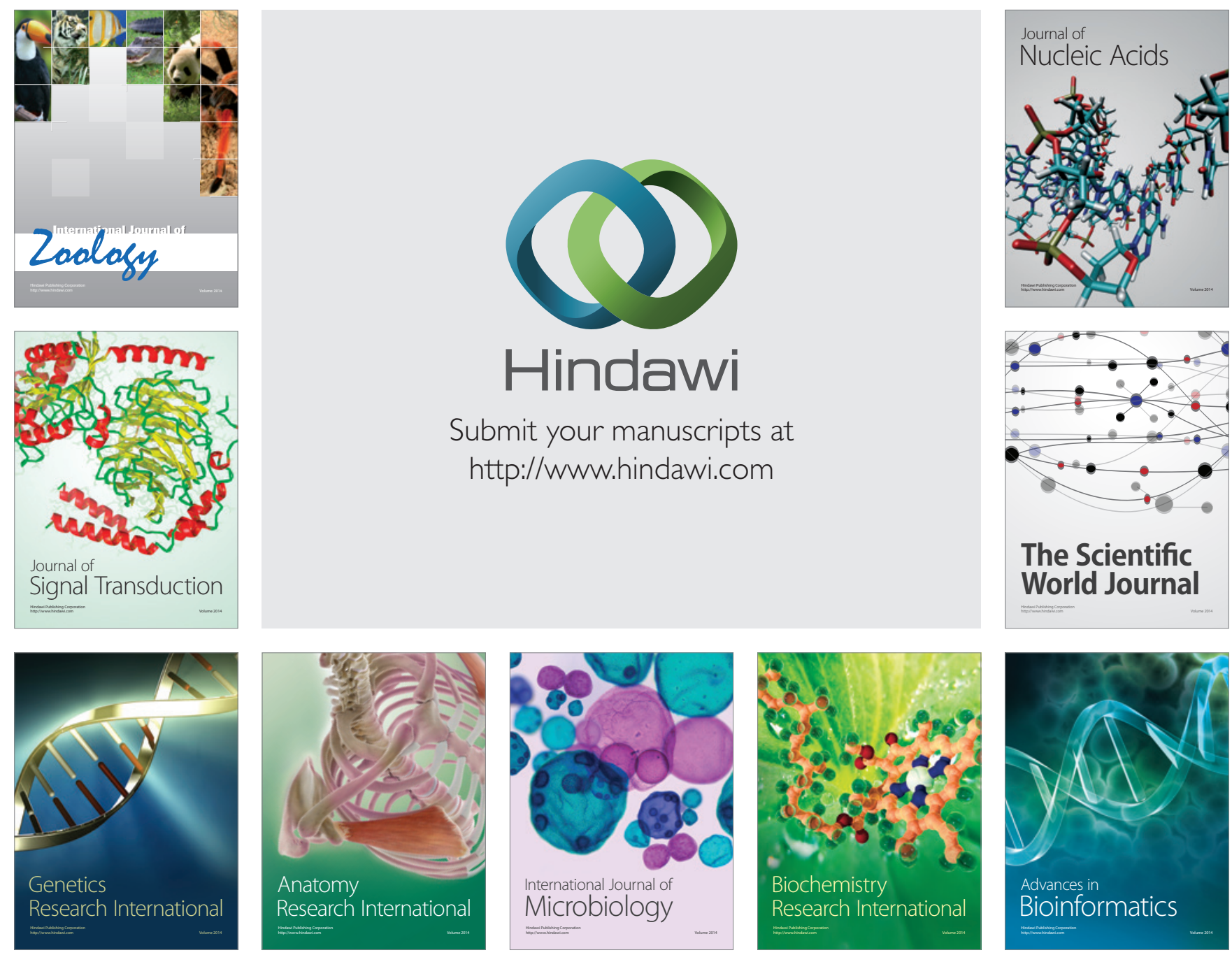

The Scientific World Journal
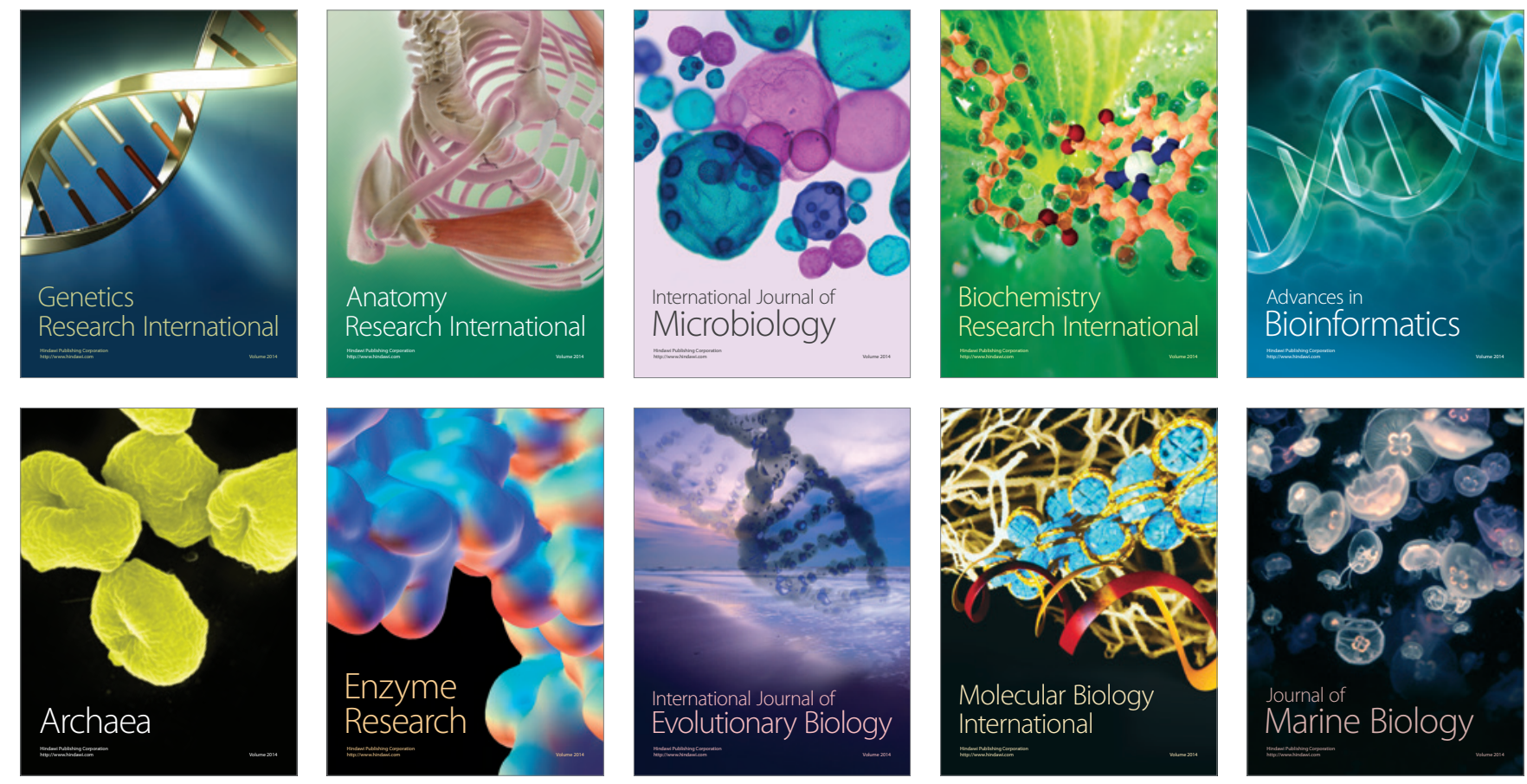